EESTI NSV TEADUSTE AKADEEMIA TOIMETISED. 29. KOIDE KEEMIA. 1980, NR. 2

ИЗВЕСТИЯ АКАДЕМИИ НАУК ЭСТОНСКОП ССР. ТОМ 29 ХимИя. 1980, № 2

\title{
ИССЛЕДОВАНИЕ ВОЗМОЖНОСТИ СТАБИЛИЗАЦИИ ПРОСТАГЛАНДИН-СИНТЕТАЗЫ МЕТОДОМ ВКЛЮЧЕНИЯ В ТВЕРДЫЕ ГЕЛИ
}

Несмотря на большие успехи тотального синтеза простагландинов (ПГ), получение их путем биохимической окислительной циклизации полиеновых кислот остается до сих пор препаративным методом изготовления природных ПГ в небольших масштабах [']. При этом ПГ-синтетаза комплекс энзимов, требующий кофакторов [ $\left.{ }^{2}\right]$ и подвергающийся в ходе реакции автокаталитической деструкции [3], - применяется либо в виде гомогената, либо в виде т. н. ацетонового порошка (АП) [4]. Поэтому для увеличения масштабов препаративного биосинтеза ПГ большой интерес представляет стабилизация энзимов путем их иммобилизации [5, $]$. Данные о стабилизации ПГ-синтетазы до сих пор отсутствуют [6], однако имеется пример ее включения в силикагель [7].

Цель настоящей работы заключалась в исследовании возможности стабнлизации ПГ-синтетазы путем включения ее в твердые гели, в частности в силикагель и полиакриламидный гель (ПААГ).

\section{Экспернментальная часть}

Выделение ПГ-синтетазы в виде АП из семенных пузырьков барана, биосинтез и определение ПГ $E_{2}$ производились по [ $\left.{ }^{4}\right]$. Количество АП во всех опытах, включая и опыты с гельэнзимами, составляло 50 ме. Концентрации компонентов инкубационной смеси были следующими: этилендиаминтетрауксусная кислота (ЭДТА) -30 мM (pH 8,0-8,3), глутатион (GSH), гидрохинон (ГX) и арахидоновая кислота (AK), соответственно, 2,$0 ; 0,5$ и 0,4 мM. Значение коэффициента экстинкции ПГ $E_{2}$ принималось равным $22000 \Omega /$ моль.см. С делью определения стабильности синтетазы при многократном использовании АП или гельэнзима инкубационную смесь перед подкислением центрифугировали при $5000 \mathrm{~g}$ в течение 10 мин. Супернатант декантировали, подкисляли лимонной кислотой и определяли количество образовавшегося ПГ $E_{2}$. K осадку добавляли необходимые компоненты и вновь инкубировали. Описанные операции повторяли до тех пор, пока фермент сохранял еще какую-либо активность. Кинетические свойства гельэнзимов изучались также методом измерения кинетики поглощения кислорода с помощью кислородного электрода [8].

Включение АП в силикагель. Силиказоль готовнли по модифицированному методу [?]

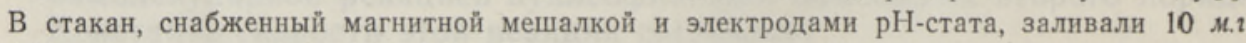
0,031 н. раствора $\mathrm{HCl}(\mathrm{pH} 1,6)$. К раствору кислоты постепенно добавляли $50 \mathrm{Mn}$ насыщенного при $50{ }^{\circ} \mathrm{C}$ раствора м-силиката натрия $\left(\mathrm{Na}_{2} \mathrm{SiO}_{3} \cdot 9 \mathrm{H}_{2} \mathrm{O}\right)$, охлажденного до комнатной температуры. Постоянное значение $\mathrm{pH} 1,6$ поддерживалось в стакане 2 н.

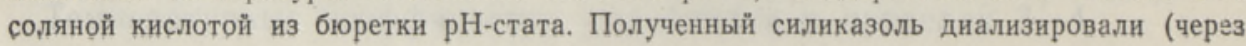


целлофан) от 0,031 н. раствора $\mathrm{HCl}(4 \Omega)$ в течение суток. Выход золя составлял 90 м.. Для инициирования гелеобразования к 15 м.л диализированного силиказоля добавляли 30 ме $\mathrm{KH}_{2} \mathrm{PO}_{4}$ и поднимали $\mathrm{pH}$ до 6. Затем добавляли 100 мә АП, перемешивали и поднимали $\mathrm{pH}$ смеси до 8,0 ( 3 н. $\mathrm{NaOH})$. Гелеобразование и сушку проводили совмещенно в ротационном испарителе под вакуумом при $25^{\circ}$ в течение $2,5-3$ \%. Выход гельэнзима составил $1,9-2,0$ ә. В некоторых случаях гелирование силиказоля с добавленными к нему $\mathrm{KH}_{2} \mathrm{PO}_{4}$ и АП проводили в стакане объемом 50 мл. После образования геля пробы замораживали жидким азотом и помещали в лиофилизатор (ОЕ-950, Венгрия). Продолжительность лиофилизации 5 ч.

Включение АП в ПААГ. Полимер готовили по модифицированному методу $\left[{ }^{9,10}\right]$. Полимеризацию мономеров проводили в стакане емкостью 50 мл. Объем смеси мономеров 4 мл. Концентрация раствора акриламида (AА) 400 $2 / \Omega$, концентрация $\mathrm{N}, \mathrm{N}^{\prime}$. метилен-бис-акриламида составляла 23 г/л (насыщенный раствор). Количество мономеров в различных опытах варьировали. Мономеры растворяли в буферных растворах $0,1 \mathrm{M} \mathrm{KH}_{2} \mathrm{PO}_{4}$ или 0,03 M ЭДТА ( $\mathrm{pH}$ которых, соответственно, 7,4 и 8,0 ) и в $0,37 \%$-ном растворе Твин-40. Смесь мономеров продували аргоном в течение 10 мин, добавляли АП (50 мح) и растворенные в воде $(0,5 \mathrm{Mz} / \mathrm{M})$ рибофлавин и тетраметилэтилендиамин $(10 \%)$ по 2 капли из капиллярной пипетки. Затем была проведена полимеризация смеси облучением УФ-светом с помощью облучателя типа 12 МО.081.019 при охлаждении смеси льдом до постоянной плотности смеси. Оценку механических свойств ПААГ проводили органолептически по пятибальной системе. Полученный гель продавливали через медицинский шприц без иглы и промывали 10 раз декантацией в соответствующем буферном растворе. До биосинтеза буферный раствор удаляли фильтрацией пробы через нутчфильтр.

Опыты с АП, включенным в ПААГ, в колонке. Опыты проводили в стеклянной термостатированной при $31^{\circ}$ колонке (внутр. диам. 7 мм), содержащей 7,5 г гельэнзима (150 мг АП). Высота столба гельэнзима - $10 \mathrm{~cm}$. Инкубационная смесь (30 мМ ЭДТА, $\mathrm{pH} 8,3 ; 2 м M \mathrm{GSH} ; 0,5$ мM ГX; 0,28 мM AK) подавалась в колонку снизу посредством перистальтического насоса со скоростью 0,5 мл/мин и собиралась сверху фракциями по 10 мл. Фракции подкисляли 2 н. лимонной кислотой до $\mathrm{pH} 3-4$ и определяли содержание образовавшегося ПГ $E_{2}$.

Эксперименты с трипсином. Трипсин (фирмы SOFA, Чехословакия; активность по гидролизу $\alpha$-бензоиларгинина - ЭЭБА $-0,025$ г.экв./2.мин) включали в силикагель аналогично АП. В опытах с гельэнзимом в колонке использовали фракцию $0,2-0,63$ м.и, активность которой составляла $35,3 \%$ активности нативного трипсина. Через термостатированную при $25^{\circ}$ стеклянную колонку с внутренним диаметром 5 мм (1,36 г гельэнзима и 3,95 ме трипсина) пропускали раствор, содержащий 1 г/л ЭЭБА, 680 ме/л $\mathrm{KH}_{2} \mathrm{PO}_{4}$ и $400 \mu z / \Omega \mathrm{SiO}_{2}\left(1,8933\right.$ z/ $\left.\mathrm{Na}_{2} \mathrm{SiO}_{3} \cdot 9 \mathrm{H}_{2} \mathrm{O}\right)$, pH раствора 8,0. Средняя скорость подачи раствора в течение 4 сут составляла 0,3 мл/мин.

\section{Результаты экспериментов}

По внешнему виду гельэнзим, полученный путем включения АП в силикагель, представлял собой бледно-желтоватые крупинки (обезвоживание в ротационном испарителе) или белый пылевидный порошок (лиофилизация). Активность гельэнзима, независимо от способа обезвоживания, составляла $50-60 \%$ от активности свободного АП (по выходу ПГ $E_{2} ;$ рисунок, $\left.1,2,9\right)$, что соответствует результатам [7]. Однако при повторных инкубациях активности обеих проб снижались и постепенно принимали близкие значения. Добавка в процессе иммобилизации АK и ПГ $E_{2}$ (по $0,14 м M$ ) или варьирование $\mathrm{pH}$ инкубационной смеси не привели к постоянному значению активности гельэнзима при повторных 


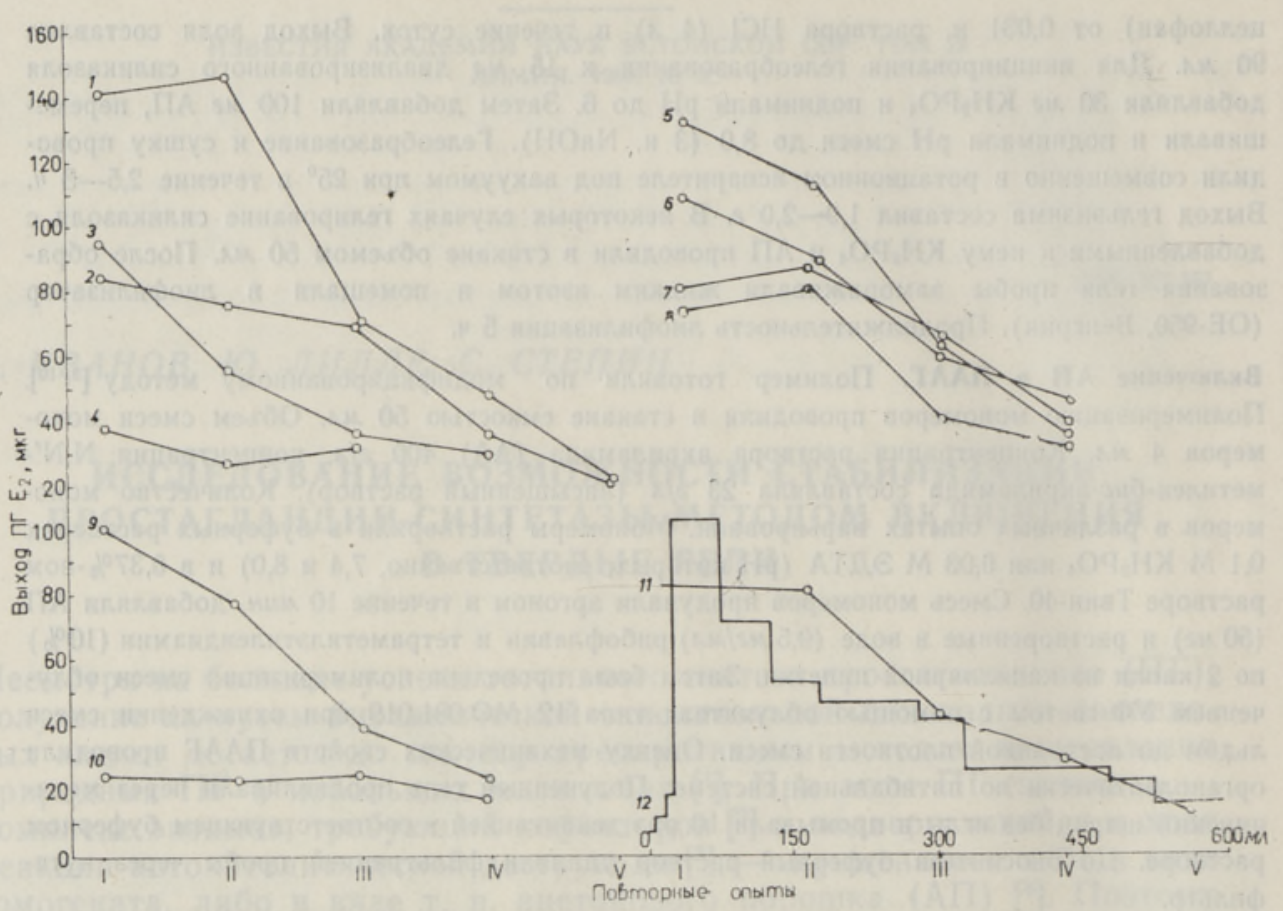

Выход ПГ $E_{2}$ в зависимости от условий иммобилизации и инкубации. $1-\mathrm{AП;} 2-10-$ АП, включенный в силикагель; 11-12 - АП, включенный в ПААГ; 3-4 - добавка при иммобилизации соответственно ПГ $E_{2}$ и АК; $5-8-\mathrm{pH}$ инкубации, соответственно, 7,$6 ; 8,0 ; 7,5$ и 8,$5 ; 9,10$ - соответственно лиофилизованный гельэнзим и он же после хранения в течение 15 сут; 12 - содержание ПГ $E_{2}$ в инкубационной смеси после колонки.

инкубациях (рисунок, $3-8$ ). При хранении при $-5^{\circ}$ под аргоном несколько более стабильным оказался лиофилизованный гельэнзим, хотя и он после 15 сут сохранил лишь $25 \%$ от соответствующей активности АП (рисунок, 10).

Таким образом, методом включения в силикагель не удалось добиться стабилизации активности синтетазы. В то же время включенный в аналогичных условиях в силикагель трипсин (с выходом $50 \%$ от первоначальной активности) не терял в непрерывно работающей колонке своей активности в течение 4 сут, при этом было гидролизовано около 0,85 г ЭЭБА (около $50 \%$ от всего пропущенного через колонку количества).

Механические свойства ПААГ после включения АП улучшаются с увеличением как общего содержания мономеров, так и относительного содержания AA (табл. 1). Однако более активными оказались менее стойкие гели. Длительное время полимеризации в основном отрицательно отражалось на активности геля. Поэтому в присутствии гемоглобина $(1, м \kappa M)$ и триптофана $(1, M M)$ образовались весьма нестойкие гели. Применение некоторых добавок в смеси мономеров полностью препятствовало гелеобразованию. Например, при добавлении к смеси мономеров диэтилдитиокарбамата $(5, M M)$ или ГХ $(0,5, M M)$ гелеобразование не началось даже по прошествии 60 мин. Попытки заменить АП на более активные гомогенат или микросомную фракцию семенных пузырьков по той же причине были безуопешными. Изменение активности гельэнзима при его многократном использовании аналогично по своему 
Результаты включения синтетазы в ПААГ

\begin{tabular}{|c|c|c|c|c|c|}
\hline $\begin{array}{c}\text { Вес мо- } \\
\text { номеров } \\
\text { на } 100 \mathrm{Mn} \\
\text { раствора, } \\
2\end{array}$ & $\begin{array}{c}\mathrm{N}, \mathrm{N}^{\prime} \text {-мети- } \\
\text { лен-бис- } \\
\text { акриламид в } \\
\text { смеси моно- } \\
\text { меров, \% }\end{array}$ & Растворитель & $\begin{array}{c}\text { Время } \\
\text { гелеобра- } \\
\text { зования, } \\
\text { мин }\end{array}$ & $\begin{array}{l}\text { Каче- } \\
\text { ство } \\
\text { ПААГ }\end{array}$ & $\begin{array}{l}\text { Актив- } \\
\text { ность } \\
\text { гельэн- } \\
\text { зима, \% }\end{array}$ \\
\hline $\begin{array}{r}21,1 \\
14,8 \\
14,8 \\
14,8 \\
9,8 \\
14,2\end{array}$ & $\begin{array}{r}5,4 \\
10,3 \\
10,3 \\
10,3 \\
18,7 \\
10,3\end{array}$ & $\begin{array}{c}0,1 \mathrm{M} \mathrm{KH}_{2} \mathrm{PO}_{4} \\
" ” \\
0,03 \mathrm{M}^{\prime \prime} \mathrm{KLTA} \\
0,1 \mathrm{MH}_{2} \mathrm{PO}_{4} \\
0,37 \% \text {-ный Твин-40 }\end{array}$ & $\begin{array}{r}4 \\
2 \\
3 \\
12 \\
20 \\
8\end{array}$ & $\begin{array}{l}5 \\
4 \\
3 \\
2 \\
3 \\
3\end{array}$ & $\begin{array}{c}29,5 \\
10,6 \\
73,5 \\
44,0 \\
57,3 \\
0\end{array}$ \\
\hline
\end{tabular}

Таблица 2 характеру изменению акРезультаты хранения синтетазы, включенной в ПААГ, Тивности АП, вКлюченв течение 10 сут при $4{ }^{\circ} \mathrm{C}$

\begin{tabular}{c|c|c}
\hline \multirow{2}{*}{ Среда } & \multicolumn{2}{|c|}{ Выход ПГ $E_{2}$} \\
\cline { 2 - 2 } & мк2 & $\%$ \\
\hline
\end{tabular}
ного в силикагель (рисунок, 11). Вследствие нестабильности гельэнзима общий выход ПГ $E_{2}$, полученного в колонке после 20 непрерывной рабо-

0,03 М ӘДТА, pH 8,0

ЭДТА-глицерин 1:1

Глицерин-вода $1: 1$

Глицерин-вода $1: 5$

$0,25 \mathrm{M}$ раствор сахарозы

Насыщенный раствор сахарозы

Контроль (без хранения)

$\begin{array}{rr}25,2 & 41,0 \\ 17,3 & 28,2 \\ 28,4 & 46,2 \\ 23,7 & 38,6 \\ 34,7 & 56,7 \\ 59,9 & 97,5 \\ 61,5 & 100,0\end{array}$
ты, - одного порядка с выходом после десятикратного применения АП [4] (рисунок, 12).

Добавление к инкубационной смеси гемоглобина и триптофана не привело к существенным изменениям характера кривой выхода ПГ $E_{2}$, приближающейся после пропускания 300 мл смеси асимптотически к нулю.

Для хранения гельэнзима наиболее подходящим оказался насыщенный раствор сахарозы (табл. 2).

При изучении кинетики поглощения кислорода были получены для обоих изученных типов гельэнзимов кривые, характерные для биохимического окисления в присутствии ПГ-синтетазы. Значение коэффициента инактивации для гельэнзима на базе силикагеля составляло 0,48 $\mathbf{M u H}^{-1}$.

Полученные результаты показали, что включение АП в ПААГ или силикагель не стабилизирует его каталитической активности в процессе биосинтеза ПГ.

\section{Заключение}

Включение ПГ-синтетазы в виде АП в такие твердые гели, как силикагель и ПААГ, позволяет в принципе улучшить ее физические свойства и тем самым облегчить применение синтетазы в биосинтезе ПГ. Однако избежать автокаталитической инактивации синтетазы в ходе биосинтеза этим методом пока не удалось. Для решения проблемы стабилизации ПГ-синтетазы требуются дальнейшие исследования роли кофакторов, механизма инактивации и привлечение более эффективных методов иммобилизацин. 
ЛИТЕРАТ У РА

1. Colbert, J. C. Prostaglandins. Isolation and synthesis. VIII. New York, London, 1973, p. 68-96.

2. Hemler, M. E., Lands, W. E. M. Biosynthesis of prostaglandins. - Lipids, 1977 , v. 12 , N 7, p. $591-595$.

3. Eg a n, R. W., Paxto n, J., Kuehl, Fr. A. Jr. Mechanism for irreversible self-deactivation of prostaglandin synthetase. - J. Biol. Chem., 1976, v. 251, N 23, p. $7329-7335$.

4. Wall a ch, D. P., Daniels, E. G. Properties of a novel preparation of prostaglandin synthetase from sheep seminal vesicles. - Biochim. Biophys. Acta, 1971 , v. 231 , p. $445-457$.

5. Messing, R. A. Immobilized enzymes for industrial reactors. New York, San Francisco, London, 1975.

6. Бе резин И. В., Антонов В. К., М артинек К. Иммобилизованные ферменты. Т. 1, 2. М., 1976.

7. Boldingh, J., Okkerse, P. P. SFV, N 19993447, 1970.

8. Лилле Ю., См ородин Е., Марвет Р. О кинетических свойствах простагландин-эндопероксид синтетазы. - Изв. АН ЭССР. Хим., 1979, т. 28, № 2, c. $108-112$.

9. Hicks, G. P., Updike, S. J. The preparation and characterization of lyophilized polyacrylamide enzyme gels for chemical analysis. - Analyt. Chem., 1966 , v. 38 , p. $726-728$.

10. Па ппель К. Э., Кестне р А. И., Тихоми рова А. С. Получение иммобилизованной $\beta$-галактозидазы. - Тр. Таллинск. политех. ин-та, 1974 , № 367 , c. $35-40$.

Институт химии
Академии наук Эстонской ССР

Поступила в редакцию 6/IV 1979

A. IVANOV, O. LILLE, S. STJOPIN

\section{PROSTAGLANDIINI SUNTETAASI STABILISEERIMISE VÕIMALUSTEST TAHKETESSE GEELIDESSE SISESTAMISE TEEL}

Artikkel käsitleb prostaglandiini $E_{2}$ saagise suurendamise võimalusi preparatiivses biosünteesis jäära seemnepōiekestest atsetoonipulbrina eraldatud ja immobiliseeritud prostaglandiini süntetaasi toimel. Silikageeli ja polüakrüülamiidgeeli baasil saadud geelensüümid omasid $50-60 \%$ lähteensüümi aktiivsusest $\mathrm{ja}$ inaktiveerusid biosünteesis analoogiliselt viimasega.

\section{A. IVANOV, O. LILLE, S. STYOPIN}

\section{ON THE POSSIBILITIES OF STABILIZATION OF PROSTAGLANDIN SYNTHETASE BY ENTRAPMENT IN SOLID GELS}

PG-synthetase in the state of acetone powder was entrapped in silica gel and polyacrylamide gel with yields of $50-60 \%$ from initial activity. Cycling the entrapped enzymes in batch and fluidized bed reactors showed a loss of activity analogous to that of acetone powder. Addition of cofactors and other ingredients did not prevent the inactivation of synthetase taking place during the course of biosynthesis. 